\title{
Maternal autonomy and the rights of the unborn child: a necessary discussion
}

\author{
Fábio Roberto Cabar ${ }^{1 *}$ (1), Gabriela Aparecida Marson Binotti²
}

\begin{abstract}
SUMMARY
OBJECTIVE: This study aimed to compare the opinion of freshmen and fifth-year students of the University of Sao Paulo School of Law in relation to the respect for maternal autonomy and knowledge of the existence and the need to protect the unborn child. METHODS: Information was obtained from a questionnaire; responses were compared with appropriate statistical methods. RESULTS: In total, 403 students answered the questionnaire, $75.2 \%$ being first-year students; $58.6 \%$ of the students were against State intervention in maternal autonomy, with no difference between groups. However, $55.1 \%$ of students were in favor of the defense of the welfare of the unborn, with the statistical difference between groups.

CONCLUSIONS: Among the first-year students, there is a contradiction about respect for maternal autonomy. Among the fifth-year students, most of them were unreservedly in favor of respect for maternal autonomy.

KEYWORDS: Personal autonomy. Fetus. Bioethics. Jurisprudence.
\end{abstract}

\section{INTRODUCTION}

Autonomy is associated with individual freedom, i.e., based on will. The patient has the right to consent or refuse procedures, diagnoses, or therapies to be performed, in a free, voluntary, and informed manner. Although it is not the treatment preferred by the physician, the patient's will prevails over the purely technical and professional decision. But, what about when the exercise of autonomy directly influences the fundamental rights of third parties?

Unborn is "one who is to be born," who was begotten and not yet born. The law protects his/her future rights so that it is not just the newly born who has legal protection. With regard to public law, the State protects the fetus by criminalizing induced abortion, so that the romanistic principles that a woman can freely dispose of her body and that the fetus is only "portio viscerum matris" are not accepted in Brazilian legislation, except in few situations.
But who is legitimate to decide on abortion and under what circumstances: the woman, the couple, society, the judicial, legislative, or medical institutions?

From a bioethical point of view, the legal prohibition of performing abortions confronts the ethical principle of beneficence and autonomy. The fetus is only protected by criminal law in cases of abortion, as it is not possible to criminalize the pregnant woman or the doctor in case of other damage, intentional or not, caused to the fetus. Thus, can the pregnant woman, in order to exercise her autonomy, put the fetus at risk? Whose task is it to protect the future of the fetus? These questions are still unanswered due to a Brazilian legislative insufficiency related to the protection of the unborn child.

\section{METHODS}

This prospective, cross-sectional study aimed to compare the opinion of freshmen and fifth-year students at the University

\footnotetext{
'Universidade de São Paulo, Faculdade de Medicina, Departamento de Obstetrícia e Ginecologia - São Paulo (SP), Brazil.

${ }^{2}$ Centro Universitário das Américas, Faculdade de Medicina - São Paulo (SP), Brazil.

*Corresponding author: fabio.cabar@hc.fm.usp.br

Conflicts of interest: the authors declare there are no conflicts of interest. Funding: none.

Received on July 21, 2021. Accepted on July 22, 2021.
} 
of São Paulo School of Law (FDUSP) regarding respect for maternal autonomy and the existence and need to protect the unborn child.

A questionnaire was applied to those students who were selected according to the following inclusion criteria: being first-year or fifth-year student at FDUSP and having signed the free and informed consent form. Students who answered the questionnaire inappropriately and who dropped out after signing the consent form were excluded. Questionnaires were administered in person or by email.

Responses were statistically assessed, and quantitative measures were assessed using mean, median, minimum, and maximum; qualitative variables were evaluated using absolute and relative frequencies (\%). To assess the association between two qualitative variables, the $\chi^{2}$ test or Fisher's exact test was considered, when appropriate. When the aim was to compare the means of two independent samples, the $t$-test was considered. The significance level adopted was 5\%.

\section{RESULTS}

Of the 900 students enrolled in the first or fifth year at FDUSP, 403 (44.8\%) answered the questionnaire, of whom 300 being first-year students and 103 being fifth-year students, and $53.8 \%$ were women, $97 \%$ were single, and only $2.5 \%$ had children. The mean age was 21.2 years, with a standard deviation of 5.2 years. When the groups were compared, it was observed that the sample of first-year students was more homogeneous in terms of gender than the sample of the fifth-year students: while in the first-year students $47.8 \%$ of respondents were females, in the fifth-year students, $72 \%$ of respondents were females. This difference was statistically significant, with $\mathrm{p}<0.001$ ( $\chi^{2}$ test). There was no statistically significant difference between the groups regarding the marital status of the participants ( $\mathrm{p}=0.59$ - Fisher's exact test) and the presence of children ( $\mathrm{p}=0.273$ - Fisher's exact test).

\section{Toward maternal autonomy}

When asked about the court decision that subjected a pregnant woman to perform a cesarean against her will, $58.6 \%$ of the students said that they were against this decision. When the responses of the two groups were compared, there was no statistically significant difference between them, both groups disagreeing with the position taken by the judge of Law: $58.7 \%$ of the first-year students disagreed with the judge, while $58 \%$ of the fifth-year students had such opinion ( $\mathrm{p}=0.907-\chi^{2}$ test). Such response pattern shows that, in this type of situation, most of both groups would respect the pregnant woman's decision.
Students were also asked about the decision of an HIV-positive pregnant woman who refuses to take antiretroviral drugs during pregnancy, exposing the fetus to the risk of intrauterine infection. In this case, most students (55.1\%) disagreed with the pregnant woman's opinion; in the analysis of the groups, $60.7 \%$ of the first-year students disagreed with the pregnant woman's decision, while $38 \%$ of the fifth-year students had the same opinion. This difference was statistically significant $\left(\mathrm{p}<0.001-\chi^{2}\right.$ test $)$.

When asked about possible punishment for this pregnant woman, $60.5 \%$ answered that the pregnant woman who neglected the use of antiretroviral medication should be punished. Thus, $62.7 \%$ of the first-year students answered that the pregnant woman should be punished, while $54 \%$ of the fifth-year students had the same opinion. There was no statistically significant difference between groups $\left(\mathrm{p}=0.127-\chi^{2}\right.$ test).

\section{Necessity and legal existence of protection for the unborn child}

Students were asked if they believed that the legal protection of the unborn child was necessary: $85.6 \%$ answered YES and that this protection is necessary, with a statistically significant difference between the groups ( $\mathrm{p}=0.034-\chi^{2}$ test): $83.5 \%$ of first-year students approve the legal protection of the unborn child, and $92 \%$ of fifth-year students have the same opinion.

In total, $90.1 \%$ of students responded that the unborn child is protected by civil law. Among the first-year students, $87.5 \%$ believe that the unborn child is civilly protected, while $98 \%$ of fifth-year students have the same opinion. This difference was statistically significant ( $\mathrm{p}=0.002-$ Fisher's exact test).

With regard to criminal protection, $81.1 \%$ of all respondents answered that the unborn child is protected by criminal law. In the group of first-year students, $80.2 \%$ believe that the unborn child is protected by criminal law; among the fifth-year students, this number rose to $84 \%$ without, however, reaching a statistical difference ( $\mathrm{p}=0.462$ - Fisher's exact test).

\section{Relationship between maternal autonomy and the rights of the unborn child}

Among those who responded that abortion should always be legalized, $78.2 \%$ responded that the unborn child should be protected by law. Still, all students who are in favor of banning abortion are in favor of legal protection for the unborn child. This difference was statistically significant $(\mathrm{p}<0.001)$.

When the groups are analyzed, it is observed that $72 \%$ of the first-year students who defend the liberation of abortion also defend the legal protection of the unborn child. When analyzing the data referring to the answers of the fifth-year students, it is noticed that $90.5 \%$ of the students who are in favor 
of the unrestricted legalization of abortion are also in favor of legal protection for the unborn child. Only $8 \%$ of fifth-year students believe that legal protection for the unborn child is not necessary.

Comparing the groups, $71.4 \%$ of the first-year students who are in favor of allowing abortion are in favor of the autonomy of the pregnant woman, that is, they do not agree with the performance of a cesarean by court decision. Among the fifth-year students, $69.1 \%$ of those who are in favor of allowing abortion are also in favor of maternal autonomy when deciding on the mode of delivery and do not accept that a court decision determines that a cesarean is performed.

The answers were compared, within the groups, in respect of the opinion regarding the legalization of abortion and the legal position to be adopted regarding the pregnant woman who decides not to undergo medical treatment during pregnancy. Among the first-year students, $60.7 \%$ would not respect the pregnant woman's decision; of those who defend maternal autonomy when performing an abortion, $51.8 \%$ would not respect maternal autonomy when she decided not to take the medication. Among the fifth-year students, 38\% would not respect the pregnant woman's decision. Among those who defend the legalization of abortion, $30.9 \%$ would not respect the pregnant woman's decision not to take medication during pregnancy.

Of all students who responded to the survey, $60.5 \%$ said that pregnant women who did not take medication during pregnancy should receive a punishment. Among those who defend the legalization of abortion, $55.6 \%$ defend a punishment for pregnant woman who puts the life of the unborn child at risk.

When comparing the groups, $62.7 \%$ of the first-year students defended punishment for the pregnant woman; 59.5\% of those who defend the legalization of abortion also defend a punishment for the pregnant woman who did not take the medicine and put the unborn child's life at risk. Among the fifth-year students, 54\% defend a punishment for negligent pregnant women; among those who advocate abortion, $47.6 \%$ advocate punishment.

Among those who were against performing a cesarean by the court decision, $43.6 \%$ of them would not respect maternal autonomy with regard to their decision not to take medication during pregnancy. When the analysis is carried out by groups, among the first-year students, $48.9 \%$ of those who do not agree with the performance of a cesarean by the court decision do not respect the pregnant woman's decision. In contrast, $27.6 \%$ of fifth-year students who responded that they did not agree with a cesarean section by the court decision do not respect the pregnant woman's decision not to take medication during pregnancy.

\section{DISCUSSION}

No study in the literature can demonstrate the opinion of law students regarding the conflict between the autonomy of the pregnant woman and the right of the unborn child. Such a survey is of paramount importance, as they are future jurists who will decide cases where there is no clear legislation on this matter.

A Brazilian judge ruled that a pregnant woman, at her 42 weeks of pregnancy, had to undergo a cesarean, against her will. In the field of Medicine, the limits of medical intervention and the responsibility of the pregnant woman to assume the consequences of her choice were questioned. It is not only the autonomy and right that the woman has over her body and her life that this case is about but also the right to life that the fetus has. And the right of the unborn child? Can the mother put him/her at risk? Whose mission is it to protect it, when the actions of the pregnant woman put the life and future of the fetus at risk?

In another situation of similar confrontation between maternal autonomy and the right of the unborn child, Cabar et al. ${ }^{1}$ described the case of a child who was born and infected by HIV because his/her mother, infected by this virus, refused to take the medication that could reduce the risk of fetal infection. How should the doctor act toward this pregnant woman who rejects the beneficial treatment for her child? Should it respect the pregnant woman's autonomy and put the unborn child's life at risk? Should the jurist interfere in favor of the unborn child or should he respect the autonomy of the pregnant woman? These questions are still unanswered.

When asked about this court decision, 58.6\% of the students said they were against it, respecting the pregnant woman's decision. When asked about the decision of the HIV-positive pregnant woman who refused to take antiretroviral drugs during pregnancy, exposing the fetus to the risk of intrauterine infection, $55.1 \%$ of them disagreed with the pregnant woman's opinion, with greater discordance among the first-year students.

This pattern of responses deserves considerations: while in the first situation (judicial decision), there was a favorable position of the majority regarding respect for maternal autonomy, and in the second situation (pregnant woman with HIV), most students responded that the pregnant woman's opinion should not be respected, that is, most were in favor of fetal well-being. On the one hand, this fact may be related to the appeal of the infectious disease still without curative treatment, with serious stigma; on the other hand, it may be that the technical lack of knowledge among law students regarding the consequences of not having adequate obstetric intervention can justify such a pattern of responses.

Regarding the legal protection of the unborn child in the Brazilian legal system, the majority responded that the unborn 
child is protected by civil law, with $85.6 \%$ responding that the legal protection of the unborn child is necessary.

However, Brazil protects the health of the unborn child exclusively through the criminalization of abortion (Articles 124-128 of the Brazilian Penal Code). In other crimes that protect health (e.g., injury, infanticide, and homicide), there is no protection for the fetus, as it is not considered a living human person ${ }^{2}$, so there is a legislative insufficiency related to the legal protection of the unborn child. In most Western countries, the legislation is similar to the Brazilian one (in the sense that there is no protection for the unborn child), except for the fact that some countries allow abortion. Exceptions to this are Spain, a country in which the attitude of the doctor or the pregnant woman that may harm the physical or mental development of the fetus is considered a crime ${ }^{3}$; in the United States, there is a law that criminally punishes people who may have caused harm (including death) to unborn children, in addition to the crime of harm to the pregnant woman.

The questions to be asked at this point are as follows: how to protect the unborn child and, at the same time, respect the autonomy of the pregnant woman? How should the doctor and the lawyer behave in these situations?

In most developed countries, the legislation allows abortion to save the pregnant woman's life and to preserve her physical or mental health, when the pregnancy resulted from rape or incest, in cases of fetal anomalies, for economic or social reasons and at the request of the woman. In contrast, in Latin America and the Caribbean, abortion is allowed in few situations, especially in those associated with the preservation of the woman's life.

There is no doubt that the prohibition of abortion is a legal protection mechanism for the unborn child, but it removes the maternal autonomy to decide about her own body, preventing her from ending a pregnancy. Of the 197 students (78.2\%) who responded that abortion should always be legalized, they also responded that the unborn child should be protected by law. Such a response is inconsistent, as decriminalizing abortion means giving pregnant women the autonomy to decide whether or not to continue pregnancy. By giving women this power, the protection offered by antiabortion laws is removed from the unborn child. How to defend the legal protection of the unborn child and wish that the pregnant woman can end the pregnancy according to her own will?

Criminal Law expresses a contradiction, as it protects the right to life, by prohibiting abortion, and positions itself against the autonomy of pregnant women. However, it does not offer any other protection to the unborn child's life.

\section{CONCLUSIONS}

This cross-sectional and prospective study allowed us to conclude that among the first-year students, there is a contradiction regarding respect for maternal autonomy; in contrast, among the fifth-year students, most students were in favor of maternal autonomy.

Most students believe that there is civil and criminal legal protection for the unborn child.

There is a contradiction among most students: while they defend the legalization of abortion, they are in favor of punishing the mother who puts the life of the unborn child at risk.

\section{AUTHORS" CONTRIBUTIONS}

FRC: Conceptualization, Data curation, Formal analysis, Writing - original draft. GAMB: Formal analysis, Writing original draft.

\section{REFERENCES}

1. Cabar FR, Pereira EF, Martini D, Vilardi N, Gomes MGM. Transmissão vertical do hiv após negligência materna: da inexistência de proteção à saúde do nascituro pelo ordenamento jurídico-penal brasileiro - relato de caso. Revista Brasileira de Bioética. 2013[cited on May 23, 2021];9(Suppl. 2013):239. Available from: https:// rbbioetica.files.wordpress.com/2014/11/anais-do-xcongresso-brasileiro-de-bioc3a9tica-20131.pdf
2. Gomes MGM, Paula DMP, Pereira EAAJF, Cabar FR, NV Barberio NV. Proteção penal da integridade física do feto - estudo a partir de um caso concreto. Revista Jurídica Luso Brasileira. 2015 [cited on May 23, 2021];1(1):131-56. Available from: https://mww.cidp. pt/publicacao/revista-juridica-lusobrasileira-ano-1-2015-n-1/156

3. Motoki MS, Cabar FR, Francisco RP. Mother's freedom of choice and the rights of an unborn child: a comparison between the views of freshmen and senior medical school students. Clinics (Sao Paulo). 2016;71(10):570-4. https://doi.org/10.6061/clinics/2016(10)03 